\title{
ESTABLISHMENT OF DYNAMIC-RECRYSTALLIZATION-STATE DIAGRAM FOR HOT DEFORMATION OF 3003 ALUMINUM ALLOY
}

\author{
IZDELAVA DIAGRAMA STANJA DINAMIČNE REKRISTALIZACIJE \\ ALUMINIJEVE ZLITINE 3003
}

\author{
Guiqing Chen ${ }^{1}$, Gaosheng $\mathrm{Fu}^{2}$, Tianyun Wei ${ }^{1}$, Chaozeng Cheng ${ }^{2}$, Junde Wang ${ }^{3}$, \\ Huosheng Wang ${ }^{4}$ \\ ${ }^{1}$ Fujian Chuanzheng Communications College, Department of Mechanical Engineering, Fuzhou 350007, China \\ ${ }^{2}$ Fuzhou University, College of Materials Science and Engineering, Fuzhou 350108, China \\ ${ }^{3}$ Changji Vocational and Technical College, Department of Mechanical Engineering, Changji 831100, China \\ ${ }^{4}$ FuJian University of Technology, College of Materials Science and Engineering, Fuzhou 350118, China \\ fugaosheng@fzu.edu.cn
}

Prejem rokopisa - received: 2017-10-14; sprejem za objavo - accepted for publication: 2017-11-24

doi:10.17222/mit.2017.176

The 3003 aluminum alloy was deformed with isothermal compression in a range of deformation temperature of $300-500{ }^{\circ} \mathrm{C}$ at a strain rate of $0.01-10.0 \mathrm{~s}^{-1}$ with a Gleeble-1500 thermal simulator. The results show that the flow stress of the 3003 aluminum alloy decreases with an increase in the deformation temperature or a decrease in the strain rate. A flow-stress constitutive model was build. The critical strain and steady strain were obtained with the strain-hardening rate. The critical strain increases with an increase in the Zener-Hollomon $(Z)$ parameter, and the steady-state strain decreases with an increase in the $Z$ parameter (a decrease in the deformation temperature or increase in the strain rate). A dynamic-recrystallization (DRX) state diagram was established in accordance with the eigenvalues of the flow-stress curve. Based on a microstructure observation, it was found that the smaller the $Z$ parameter and the greater the strain, more complete was DRX.

Keywords: 3003 aluminum alloy, dynamic recrystallization, state diagram, strain-hardening rate

Avtorji prispevka so aluminijevo zlitino 3003 izotermno tlačno deformirali v območju deformacijskih temperatur med $300{ }^{\circ} \mathrm{C}$ in $500{ }^{\circ} \mathrm{C}$ pri hitrostih deformacije med $0,01 \mathrm{~s}^{-1}$ in $10,0 \mathrm{~s}^{-1}$ na termičnem simulatorju Gleeble-1500. Rezultati deformacijskih preizkusov so pokazali, da meja tečenja izbrane zlitine pada z naraščajočo temperaturo deformacije ali z zmanjševanjem hitrosti deformacije. Na osnovi preizkusov so avtorji izdelali tudi konstitutivni model za mejo tečenja v odvisnosti od temperature in hitrosti deformacije. Kritično deformacijo in stalno deformacijo so dobili s hitrostjo deformacijskega utrjevanja. Kritična deformacija je naraščala z naraščanjem Zener - Hollomonovega $(Z)$ parametra, in stanje stalne deformacije se je zmanjševalo $Z$ naraščanjem $Z$ parametra (zmanjšanje temperature deformacije ali povečevanje hitrosti deformacije). Diagram stanja dinamične rekristalizacije (DRX) so izdelali s pomočjo karakterističnih vrednosti krivulj tečenja. S kombinacijo mikrostrukturnih preiskav, manjših $Z$ parametrov in večjih deformacij, so lahko izdelali bolj celovit DRX.

Ključne besede: Al zlitina 3003, dinamična rekristalizacija, diagram stanja, hitrost deformacijskega utrjevanja

\section{INTRODUCTION}

In the aluminum-manganese alloy, the 3003 aluminum alloy has been widely used for decorative materials, heat-exchange materials, photosensitive materials, packaging materials, welding materials and so on because of its excellent comprehensive performance. ${ }^{1-2}$ Rolling deformation is an important method to obtain an excellent aluminum-alloy sheet, which plays a key role in the mechanical properties of the alloy, because the grain structure of the alloy is transformed into a flat, elongated, deformed structure during the intense plasticdeformation process. ${ }^{3-4}$ The deformation energy obtained by rolling can be used as a driving force for DRX, contributing to the improvement of the mechanical properties of the alloy. ${ }^{5-6}$ At present, a large number of studies are being carried out on the DRX of aluminum alloys during hot deformation. The studies are limited to the relationship between hot-deformation conditions (deformation temperature and strain rate) and DRX. ${ }^{7-9}$ There is little study on the impact of rolling deformation on the microstructure and properties of the 3003 aluminum alloy. The DRX of the 3003 aluminum alloy is rarely studied quantitatively, and the DRX state diagram is rarely used to study hot deformation. In order to quantitatively study the basic laws of DRX, it is necessary to know the three eigenvalues of the strain on a rheological curve: critical strain $\left(\varepsilon_{\mathrm{c}}\right)$, peak strain $\left(\varepsilon_{\mathrm{p}}\right)$ and steady-state strain $\left(\varepsilon_{\mathrm{s}}\right)$, which are closely related to the historical state of an alloy and the hot-deformation conditions. ${ }^{10}$ The critical strain and steady-state strain can be calculated from the strain-hardening rate, ${ }^{11-12}$ and the peak strain can be measured with the stress peak on a flow-stress curve. According to the three eigenvalues of the strain on the rheological curve, the DRX state diagram can be established, which can help us understand the evolution law of the DRX of the alloy. It can provide an experimental basis for optimizing the hot-processing 
technology of the 3003 aluminum alloy and effectively controlling the product quality.

\section{EXPERIMENTAL PART}

The main components of the 3003 aluminum alloy are (mass fraction/\%): $0.62 \mathrm{Fe}, 0.58 \mathrm{Si}, 1.09 \mathrm{Mn}, 0.068$ $\mathrm{Cu}, 0.006 \mathrm{Ti}, 0.03 \mathrm{Mg}, 0.007 \mathrm{Ni}, 0.008 \mathrm{Zn}$, the balance being Al. The preparation of an ingot is as follows: firstly, aluminum ingots are subjected to melt treatment in a graphite-crucible resistance furnace. ${ }^{13}$ Secondly, an ingot is poured out and heat treated $\left(510{ }^{\circ} \mathrm{C}, 20 \mathrm{~h}\right)$. Finally, a hot-compression sample is processed according to the standard. Cylindrical specimens of $10 \mathrm{~mm}$ in diameter and $15 \mathrm{~mm}$ in height are machined for hot-compression tests. Both flat ends of the specimens are recessed to a depth of $0.2 \mathrm{~mm}$ to entrap graphite powder in order to minimize the friction between the specimen surface and the clamp. The samples are mounted on a Gleeble-1500 thermal simulator for isothermal constant-strain-rate hot-compression tests. The experimental conditions for hot deformation are: the heating rate of a sample is controlled at $1{ }^{\circ} \mathrm{C} / \mathrm{s}$; insulation takes place for $5 \mathrm{~min}$ after the set temperature. The level of compression deformation is kept at 0.7 . The range of the strain rate is $0.01 \sim 10.0 \mathrm{~s}^{-1}$, and the deformation temperature is in a range of $300 \sim 500{ }^{\circ} \mathrm{C}$. The data of the experiment is controlled and collected by the computer. The deformed specimens are quenched in water quickly after each compression test in order to maintain the microstructure.

For a microstructural examination, the specimens are sliced parallelly in the direction of compression. The microstructure characterization of the deformed samples is determined using an XJG-05 optical microscope (OM) and JEM-2100F transmission electron microscopy (TEM). For the microscopic examination, the specimens are mechanically polished and etched with Keller's reagent $\left(2.5 \mathrm{~mL} \mathrm{HNO}_{3}, 1.5 \mathrm{~mL} \mathrm{HCl}, 1 \mathrm{~mL} \mathrm{HF}\right.$ and $95 \mathrm{~mL} \mathrm{H}_{2} \mathrm{O}$ ). The foils used for TEM are prepared by being mechanically polished to less than $80 \mu \mathrm{m}$ and then punched into 5-mm discs. Finally, a twin-jet electro-polishing device is used to prepare samples with an electrolyte solution of $25-\%$ nitric acid and 75-\% methanol at a voltage of $\sim 15 \mathrm{~V} \mathrm{DC}$ and a temperature below $-20{ }^{\circ} \mathrm{C}$. It is remarkable to note that the TEM samples are sprayed continually until a small hole appears.

\section{RESULTS AND DISCUSSION}

\subsection{Establishment of the constitutive equation}

The deformation mechanism of an aluminum alloy is complicated at high temperature and the alloy is sensitive to the deformation temperature and strain rate. The true stress/true strain data under a certain temperature and strain rate are usually collected with a hot-compression simulation experiment. Based on these data, the material constants are calculated, and the constitutive equation is established. The peak flow stress of the material is an important characteristic parameter in the process of high-temperature deformation, and the peak stress is one of the important process parameters used to determine the material-processing technology. ${ }^{14}$ Considering that the peak flow stress occurs at the moment when the strain is small and that the change in the peak stress before and after the amendment of the temperature rise is not obvious, the constitutive equation is established by taking the true peak stress under the corresponding strain rate and deformation-temperature conditions. Figure 1 shows the true stress/true strain curves of the 3003 aluminum alloy under different deformation conditions.

The peak flow stress of the alloy is assumed to be consistent with the hyperbolic sine mathematical model proposed by Sellars and Tegart, ${ }^{15-16}$ that is in Equation (1)

$$
\dot{\varepsilon}=A[\sinh (\alpha \sigma)]^{n} \exp \left(\frac{-Q}{R T}\right)
$$

where $A$ is the constant, $\sigma$ is the flow stress, $n$ is the stress index, $Q$ is the deformation activation energy $(\mathrm{J} / \mathrm{mol}), R$ is the gas constant.
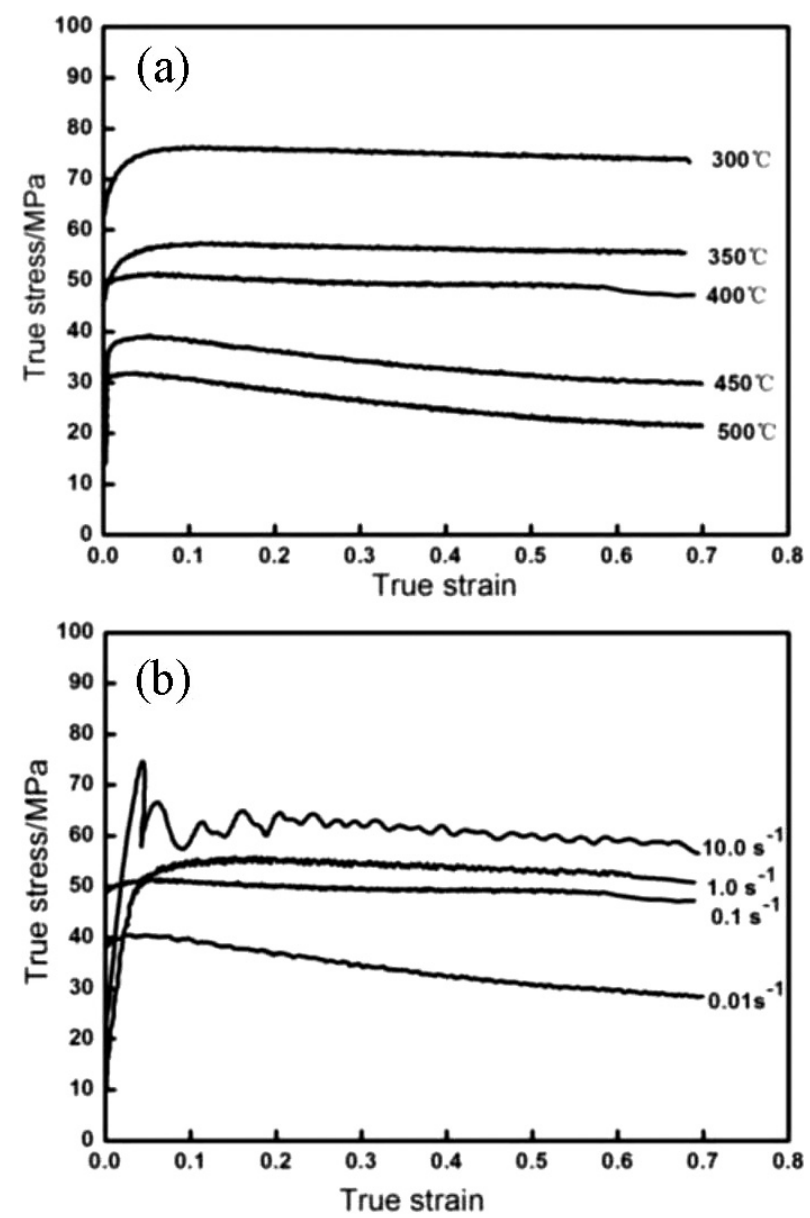

Figure 1: True stress-strain curves of 3003 aluminum alloy: a) $0.1 \mathrm{~s}^{-1}$, b) $400{ }^{\circ} \mathrm{C}$ 
Table 1: Hot-deformation material constants of 3003 aluminum alloy

\begin{tabular}{|c|c|c|c|c|c|}
\hline$n^{\prime}$ & $\beta$ & $\alpha /\left(\mathrm{mm}^{2} / \mathrm{N}\right)$ & $n$ & $D$ & $Q /\left(\mathrm{KJ} \mathrm{mol}^{-1}\right)$ \\
\hline 12.51249 & 0.20923 & 0.01672 & 9.14086 & 2.42554 & 191.79623 \\
\hline
\end{tabular}

Under low-stress conditions $(\alpha \sigma<0.8)$, Equation (1) can be transformed into a power exponential relationship:

$$
\dot{\varepsilon}=A_{1} \sigma^{n}
$$

Under high-stress conditions ( $\alpha \sigma>1.2)$, Equation (1) can be transformed into an exponential relationship:

$$
\dot{\varepsilon}=A_{2} \exp (\beta \sigma)
$$

where $A_{1}, A_{2}, n_{1}, \beta$ do not change with the changes in the deformation temperature, as they are constant, and $\alpha$ $=\beta / n_{1}$.

Assuming that the deformation activation energy cannot be affected by the deformation temperature, both sides of Equations (1), (2) and (3) were transformed respectively to obtain:

$$
\begin{gathered}
\ln \dot{\varepsilon}=n \ln [\sinh (\alpha \sigma)]+\ln C \\
\ln \dot{\varepsilon}=\ln A_{1}+n^{\prime} \ln \sigma \\
\ln \dot{\varepsilon}=\ln A_{2}+\beta s
\end{gathered}
$$

The function of the temperature and flow stress can be obtained according to Equation (1). Assuming that the hot-deformation activation energy is constant over a certain hot-deformation temperature range, and the strain rate remains constant, both sides of Equation (1) are transformed to obtain:

$$
\begin{gathered}
\ln \dot{\varepsilon}+Q / R T=n \ln [\sinh (\alpha \sigma)]+\ln A \\
\ln [\sinh (\alpha \sigma)]=E+D \frac{1000}{T} \\
\ln z=\ln A+n \ln [\sinh (\alpha \sigma)]
\end{gathered}
$$

According to Equations (4) to (9), the material constants of the 3003 aluminum alloy can be calculated as shown in Table 1.

Therefore, the constitutive model of the flow stress during high-temperature deformation is:

$\dot{\varepsilon}=2.03 \times 10^{14}[\sinh (0.01672 \times \sigma)]^{9.14086} \cdot \exp \left(-\frac{191.79623}{R T}\right)$

$$
\begin{aligned}
& \text { Or } z=\dot{\varepsilon} \cdot \exp \left(\frac{191.79623}{R T}\right) \\
& \sigma=59.81 \ln \left\{\left(\frac{z}{2.03 \times 10^{14}}\right)^{1 / 9.14086}+\left[\left(\frac{z}{2.03 \times 10^{14}}\right)^{2 / 9.14086}+1\right]^{1 / 2}\right\}
\end{aligned}
$$

Under the experimental conditions, the $Z$ value of the 3003 aluminum alloy during hot deformation can be obtained with Equation (11), as shown in Table 2.

Table 2: Ln $Z$ value of 3003 aluminum alloy under different deformation conditions

\begin{tabular}{|c|c|c|c|c|c|c|c|c|}
\hline$T /{ }^{\circ} \mathrm{C}$ & \multicolumn{4}{|c|}{400} & 300 & 350 & 450 & 500 \\
\hline$\dot{\varepsilon} / \mathrm{s}^{-1}$ & 0.01 & 0.1 & 1.0 & 10.0 & \multicolumn{3}{c|}{0.1} \\
\hline Ln $Z$ & 29.67 & 31.98 & 34.28 & 36.58 & 37.96 & 34.73 & 29.60 & 27.54 \\
\hline
\end{tabular}

\subsection{Determination of the eigenvalue of the flow-stress curve}

\subsubsection{Determination of the DRX critical strain}

Under certain deformation-temperature and strainrate conditions, the ratio of stress to strain is defined as the strain-hardening rate $(\theta)$ of the alloy: ${ }^{11}$

$$
\theta=\left(\frac{\mathrm{d} \sigma}{\mathrm{d} \varepsilon}\right)_{\dot{\varepsilon}, T}
$$

By establishing the relationship between the flow stress and the strain-hardening rate, we can further reveal the change law of the internal structure during high-temperature deformation and lay the foundation for the determination of the eigenvalue of the flow-stress curve. In accordance with the thermodynamics irreversible principle of materials, Poliak and Jonas proposed the critical kinetic conditions for the DRX of alloys ${ }^{17}$, that is, the inflection point of the curve $\theta \sim \sigma$ or the minimum value of the curve $(-\partial \theta / \partial \sigma) \sim \sigma$ corresponding to the critical condition. The flow stress corresponding to the inflection point or the minimum value is the critical stress $\left(\sigma_{c}\right)$, and
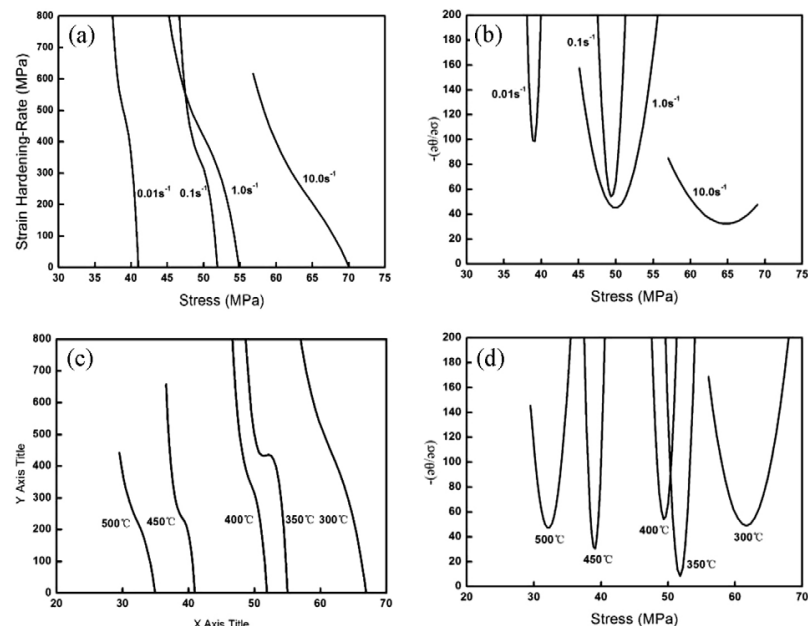

Figure 2: Relationship curves between strain-hardening rate and flow stress: a) $400{ }^{\circ} \mathrm{C}, \theta \sim \sigma$, b) $400{ }^{\circ} \mathrm{C},(-\partial \theta / \partial \sigma) \sim \sigma$, c) $0.1 \mathrm{~s}^{-1}, \theta \sim \sigma$, d) $0.1 \mathrm{~s}^{-1},(-\partial \theta / \partial \sigma) \sim \sigma$ 
G. CHEN et al.: ESTABLISHMENT OF DYNAMIC-RECRYSTALLIZATION-STATE DIAGRAM FOR HOT DEFORMATION ...

Table 3: Critical strain value of the alloy under different deformation conditions

\begin{tabular}{|c|c|c|c|c|c|c|c|c|}
\hline$T /{ }^{\circ} \mathrm{C}$ & \multicolumn{4}{|c|}{400} & 300 & 350 & 450 & 500 \\
\hline$\dot{\varepsilon} / \mathrm{s}^{-1}$ & 0.01 & 0.1 & 1.0 & 10.0 & & \multicolumn{2}{|c|}{0.1} \\
\hline$\varepsilon_{\mathrm{c}}$ & 0.02792 & 0.03765 & 0.04772 & 0.06072 & 0.06648 & 0.05399 & 0.03214 & 0.02403 \\
\hline
\end{tabular}

the strain value corresponding to the inflection point or the minimum value is the critical strain of the DRX.

According to Equation (13) of the strain-hardening rate, the curves $\theta \sim \sigma$ and $(-\partial \theta / \partial \sigma) \sim \sigma$ can be determined under the conditions of $400{ }^{\circ} \mathrm{C}(0.01,0.1,1.0$ and 10.0) $\mathrm{s}^{-1}$ and $0.1 \mathrm{~s}^{-1}\left(300,350,400,450\right.$ and 500) ${ }^{\circ} \mathrm{C}$, as shown in Figure 2.

It can be seen from Figure 2 that the flow stress corresponding to $\frac{\partial}{\partial \sigma}\left(\frac{\partial \theta}{\partial \sigma}\right)=0$ is the critical stress $\left(\sigma_{\mathrm{c}}\right)$ of the DRX, which can be obtained directly from curve $(-\partial \theta / \partial \sigma) \sim \sigma)$. The critical strain can be obtained from $\sigma_{\mathrm{c}}$ of the flow-stress curve, and the calculation results are shown in Table 3.

It can be seen from Table 3 that the DRX critical strain value of the 3003 aluminum alloy increases with
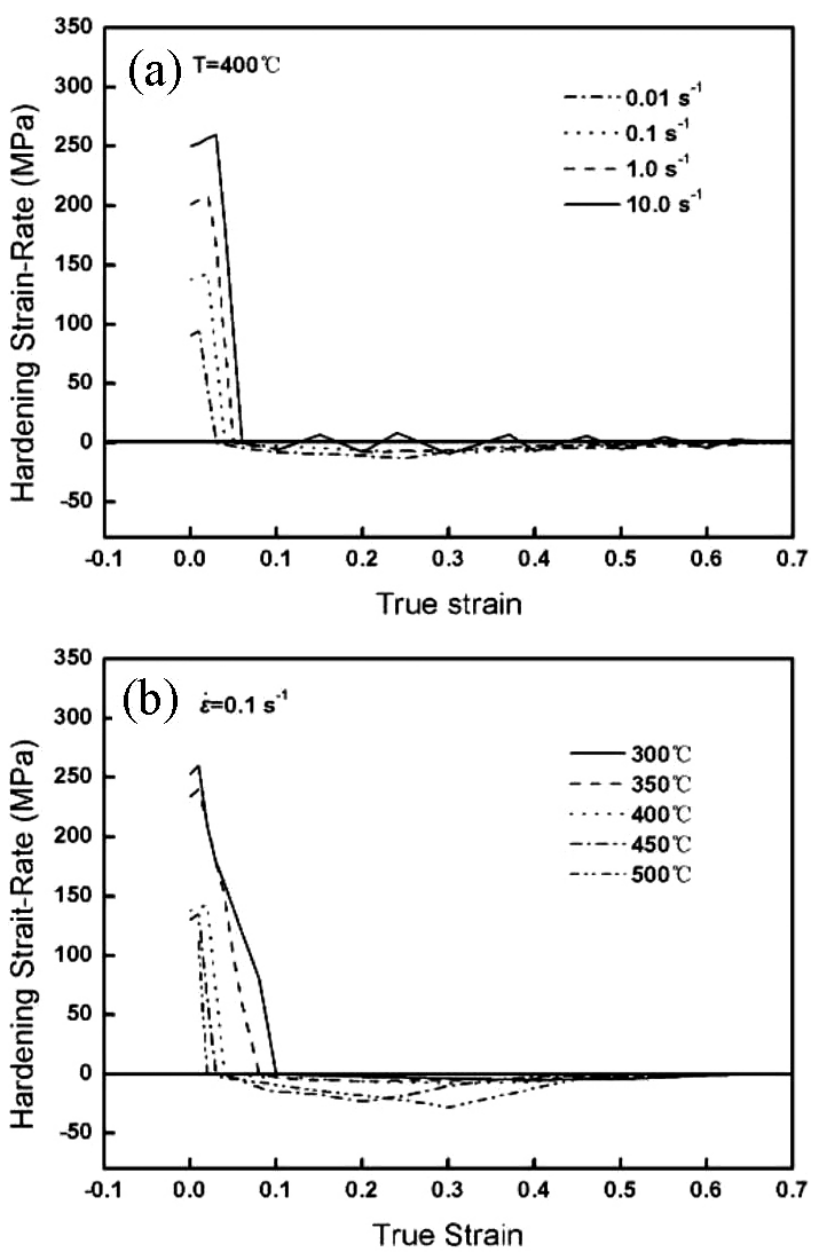

Figure 3: Relationship curves for strain-hardening rate and strain: a) $T=400{ }^{\circ} \mathrm{C}$, b) $\dot{\varepsilon}=0.1 \mathrm{~s}^{-1}$ an increase in the $Z$ parameter (a decrease in the deformation temperature or an increase in the strain rate); this is because the deformation temperature is reduced, the climb and slip of the dislocation are hindered, and the sub-crystal formation and merger are difficult, which make the DRX of the hot-deformation process difficult to occur, resulting in an increased DRX critical-strain value. On the other hand, the process of DRX is closely related to the time. The deformation time is shortened with the increase in the strain rate, and the movement and climbing of dislocations are difficult to be carried out. It affects the DRX nucleation quantity, limits the growth rate of the recrystallized grains, and weakens the softening effect of the DRX, which all lead to an increase in the critical strain value obtained with the balance of strain hardening and DRX softening. At the same time, under the higher strain-rate condition, the "adiabatic temperature-rise effect" occurs, increasing the local temperature of the material and enhancing the dynamic-recovery effect. The dislocations cancel each other out through the slips and climbs, and the dislocation density decreases. Therefore, the internal residualdeformation storage energy of the material can be reduced, and the DRX is difficult to occur, resulting in an increase in the DRX critical strain.

By comparing the critical strain values from Table 3 with the data for the peak strain from Figure 1, the relationship between them can be established (Equation (2)):

$$
\varepsilon_{\mathrm{c}}=0.689 \varepsilon_{\mathrm{p}}
$$

\subsubsection{Determination of the steady-state strain of DRX}

The DRX steady-state strain is determined with the curve of the strain-hardening rate and strain. The relationship between the strain-hardening rate and strain of the 3003 aluminum alloy is shown in Figure 3.

As can be seen from Figure 3, with the increasing strain, the strain-hardening rate reaches the maximum and then decreases to a minimum of less than 0 . When the strain-hardening rate is 0 , the corresponding strain value is the peak strain. As the strain increases, if the value of the strain-hardening rate returns to 0 and keeps the value of 0 , then a continuous DRX occurs at this point; if the strain-hardening rate fluctuates around the value of 0 , a periodic DRX occurs. When building a DRX model, the strain corresponding to the strain-hardening rate for the first time between the negative value and 0 is called the steady-state strain. ${ }^{18-19}$ The steadystate strain can be obtained with different flow-stress curves, and the parameters are shown in Table 4. 
Table 4: Steady-state-strain value under different deformation conditions

\begin{tabular}{|c|c|c|c|c|c|c|c|c|}
\hline$T /{ }^{\circ} \mathrm{C}$ & \multicolumn{4}{|c|}{400} & 300 & 350 & 450 & 500 \\
\hline$\dot{\varepsilon} / \mathrm{s}^{-1}$ & 0.01 & 0.1 & 1.0 & 10.0 & \multicolumn{3}{|c|}{0.1} & \\
\hline$\varepsilon_{\mathrm{c}}$ & 0.4285 & 0.4858 & 0.5164 & 0.6177 & 0.5312 & 0.4936 & 0.4688 & 0.4504 \\
\hline
\end{tabular}

It can be seen from Table 4 that the steady-state strain for the 3003 aluminum alloy is reduced with an increase in the deformation temperature or a decrease in the strain rate. A lower strain rate and higher deformation temperature are favorable for the balance of work hardening and softening in the case of a small strain.

\subsection{Establishment of a DRX state diagram}

The establishment of a DRX state diagram helps us understand the interval of the recrystallization process. To determine the diagram, the three characteristic values $\left(\varepsilon_{\mathrm{c}}, \varepsilon_{\mathrm{p}}\right.$ and $\left.\varepsilon_{\mathrm{s}}\right)$ of the strain on the flow-stress curve need to be known. The critical strain is obtained with the kinetic critical condition of the thermodynamic irreversible principle. The steady-state strain is determined with the curve for the strain-hardening rate versus the strain. The peak strain on the flow-stress curve can be measured from the stress peak on the curve in Figure 1. Combined with the experimental results from Table 3 and Table 4, the DRX state diagram for the 3003 aluminum alloy can be drawn (Figure 4).

It can be seen from Figure 4 that the DRX state diagram of the 3003 aluminum alloy can be divided into three areas: area I is the region where no DRX occurs, area II is the region where incomplete DRX occurs, and area III is the region where complete DRX occurs. DRX is done more completely with an increase in the strain under experimental deformation conditions. When the $Z$ parameter is reduced (deformation temperature increases or strain rate decreases), the critical strain required for the DRX slows down while the magnitude of the reduction of the steady-state strain is larger. Therefore, the critical strain is less affected by the change in the $Z$

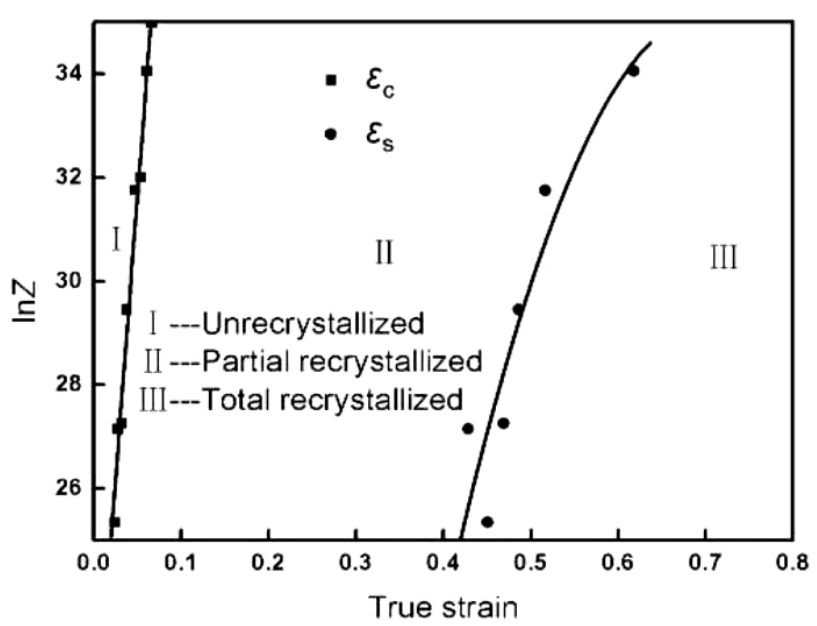

Figure 4: DRX state diagram of 3003 aluminum alloy
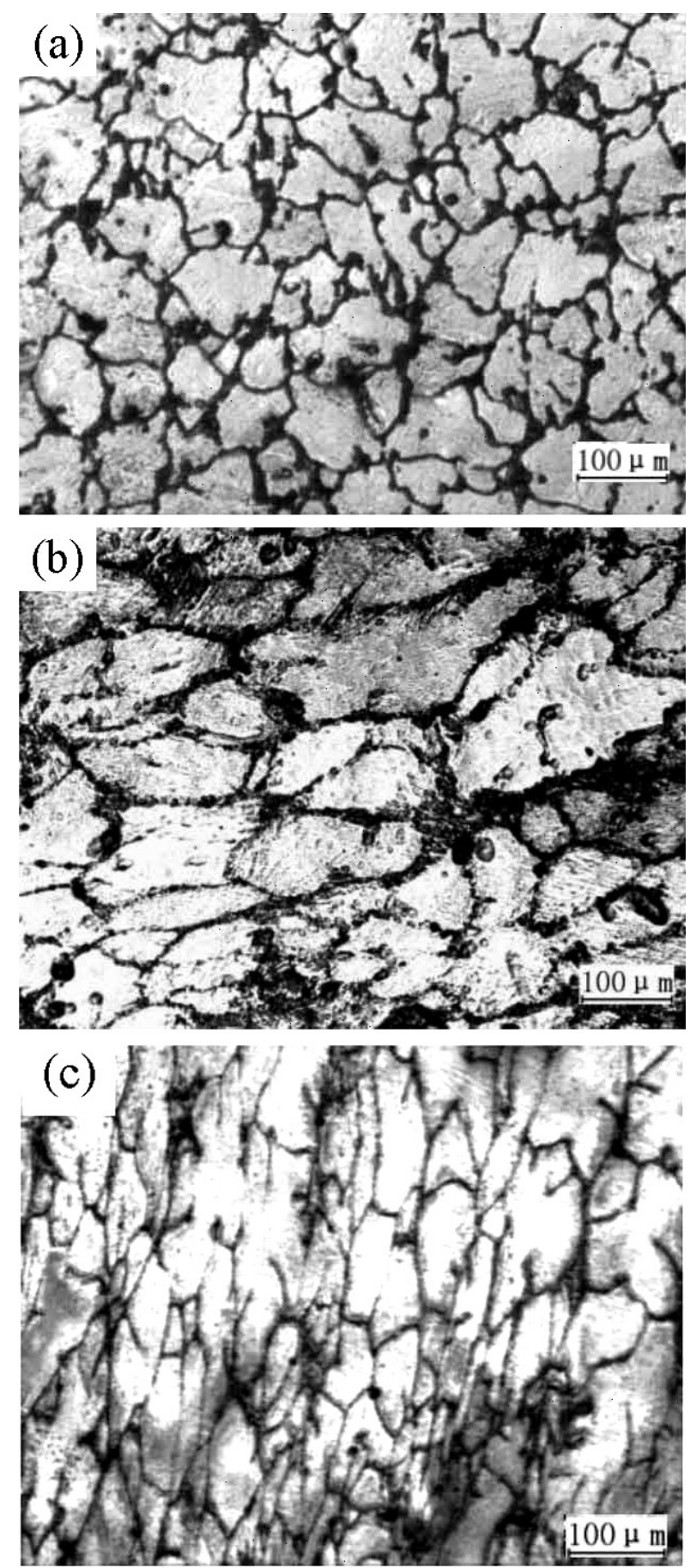

Figure 5: OM images of 3003 aluminum alloy under different deformation conditions $\left(400{ }^{\circ} \mathrm{C}, 0.1 \mathrm{~s}^{-1}\right)$ : a) not deformed, b) $30 \%$, c) $50 \%$

parameter while the steady-state strain is greatly affected by the change in the $Z$ parameter. It can be seen that the smaller the $Z$ parameter, the more favorable is the DRX of the alloy, which helps us refine the deformed grains and improve the mechanical properties of the alloy.

As seen from the hot-deformation microstructures on Figures 5 and $\mathbf{6}$, the original grains are equiaxed and the tissues are more uniform (Figure 5a) before deformation. When the level of deformation reaches $30 \%$, the 

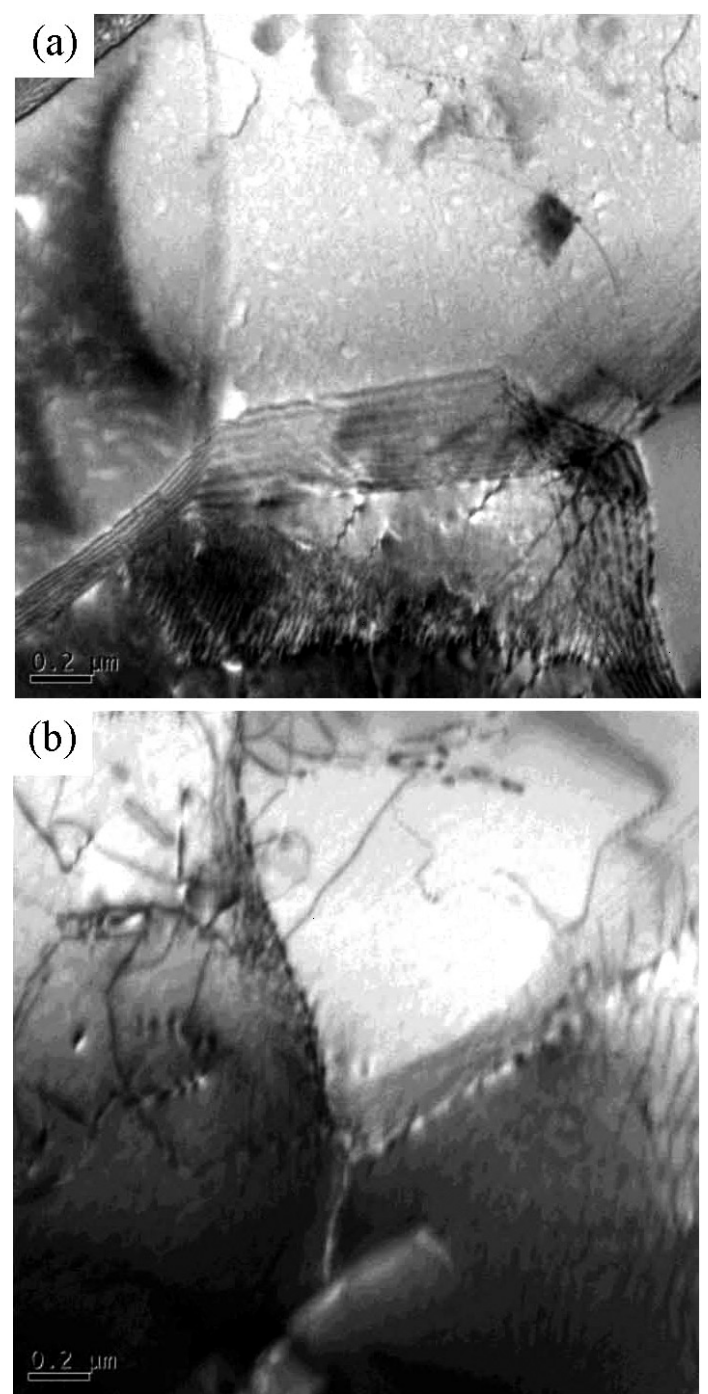

Figure 6: TEM images of 3003 aluminum alloy under different deformation conditions $\left(400{ }^{\circ} \mathrm{C}, 0.1 \mathrm{~s}^{-1}\right)$ : a) $30 \%$, b) $50 \%$

original grains are deformed, and some of the grains are elongated. Finely recrystallized grains can be observed in the local area (Figure 5b). The wall of dislocation can be clearly seen on Figure 6a, and the dislocations react and offset each other, resulting in the formation of large angle grains. When the level of deformation continues to increase to $50 \%$, more uniform, equiaxed crystals are produced, and the deformed grains are basically gone, leading to the occurrence of a new crystal nucleation and growth, and the formation of relatively complete DRX grains (Figure 5c). At this time, the dislocation in the crystals disappears, large angle grains can be observed (Figure 6b) and the DRX is carried out more fully.

\section{CONCLUSIONS}

1) The flow stress of the 3003 aluminum alloy during hot deformation is reduced with an increase in the deformation temperature or a decrease in the strain rate.
The constitutive equation of alloy is established using a hyperbolic sine mathematical model.

2) The DRX critical strain increases with an increase in the $Z$ parameter (a decrease in the deformation temperature or an increase in the strain rate). The relationship between the critical strain and peak strain is $\varepsilon_{\mathrm{c}}=$ $0.689 \varepsilon_{\mathrm{p}}$.

3) The steady-state strain is calculated using the strain-hardening rate, and its value decreases with the increase in the deformation temperature or the decrease in the strain rate.

4) In accordance with the eigenvalues of the flow-stress curve, a DRX state diagram is established. The smaller the $Z$ parameter and the larger the strain, the more favorable is the DRX of the alloy.

\section{Acknowledgments}

The authors would like to acknowledge the financial support from the Fujian Natural Science Foundation (2017J01156, 2017J01083); Xinjiang Uygur Autonomous Region, university scientific research program, scientific research key project (XJEDU2016I068); science and technology project of the Fujian Education Department (JA15659); and materials near net shape forming and digital manufacturing technology service team of the Fujian Chuanzheng Communications College of China.

\section{REFERENCES}

${ }^{1}$ Y. B. Tan, X. M. Wang, M. Ma, J. X. Zhang, W. C. Liu, R. D. Fu, and S. Xiang, A study on microstructure and mechanical properties of AA 3003 aluminum alloy joints by underwater friction stir welding, Mater. Charact., 127 (2017), 41-52, doi:10.1016/j.matchar.2017. 01.039

${ }^{2}$ G. Chen, G. Fu, H. Chen, C. Cheng, W. Yan, S. Lin, Optimization of a hot deformation process of the 3003 aluminum alloy by processing maps, Met. Mater. Int., 18 (2012) 5, 813-819, doi:10.1007/s12540012-5010-y

${ }^{3}$ J. Donoghue, A. A. Antonysamy, F. Martina, P. A. Colegrove, S. W. Williams, P. B. Prangnell, The effectiveness of combining rolling deformation with wire-arc additive manufacture on $\beta$-grain refinement and texture modification in Ti-6Al-4V, Mater. Charact., 114 (2016), 103-114, doi:10.1016/j.matchar.2016.02.001

${ }^{4}$ R. S. Nalawade, A. J. Puranik, G. Balachandran, K. N. Mahadik, V. Balasubramanian, Simulation of hot rolling deformation at intermediate passes and its industrial validity, Int. J. Mech. Sci., 77 (2013), 8-16, doi:10.1016/j.ijmecsci.2013.09.017

${ }^{5}$ T. Sakai, A. Belyakov, R. Kaibyshev, H. Miura, J. J. Jonas, Dynamic and post-dynamic recrystallization under hot, cold and severe plastic deformation conditions, Prog. Mater. Sci., 60 (2014), 130-207, doi:10.1016/j.pmatsci.2013.09.002

${ }^{6}$ G. Z. Quan, G. C. Luo, J. T. Liang, D. S. Wu, A. Mao, Q. Liu, Modelling for the dynamic recrystallization evolution of Ti-6Al-4V alloy in two-phase temperature range and a wide strain rate range, Comp. Mater. Sci., 97 (2015), 136-147, doi:10.1016/j.commatsci. 2014.10.009

${ }^{7}$ T. Sakai, H. Miura, A. Goloborodko, O. Sitdikov, Continuous dynamic recrystallization during the transient severe deformation of aluminum alloy 7475, Acta Mater., 57 (2009) 1, 153-162, doi:10.1016/j.actamat.2008.09.001 


\section{G. CHEN et al.: ESTABLISHMENT OF DYNAMIC-RECRYSTALLIZATION-STATE DIAGRAM FOR HOT DEFORMATION ...}

${ }^{8}$ G. Z. Quan, Y. P. Mao, G. S. Li, W. Q. Lv, Y. Wang, J. Zhou, A characterization for the dynamic recrystallization kinetics of as-extruded 7075 aluminum alloy based on true stress-strain curves, Comp. Mater. Sci., 55 (2012), 65-72, doi:10.1016/j.commatsci. 2011.11.031

${ }^{9}$ X. M. Chen, Y. C. Lin, D. X. Wen, J. L. Zhang, M. He, Dynamic recrystallization behavior of a typical nickel-based superalloy during hot deformation, Mater. Des., 57 (2014), 568-577, doi:10.1016/ j.matdes.2013.12.072

${ }^{10}$ G. Chen, G. Fu, W. Yan, C. Cheng, Z. Zou, Mathematical model of dynamic recrystallization of aluminum alloy 3003, Met. Sci. Heat Treat., 55 (2013) 3-4, 220-225, doi:10.1007/s11041-013-9609-5

${ }^{11}$ C. Brozek, F. Sun, P. Vermaut, Y. Millet, A. Lenain, D. Embury, P. J. Jacques, F. Prima, A $\beta$-titanium alloy with extra high strain-hardening rate: Design and mechanical properties, Scripta Mater., 114 (2016), 60-64, doi:10.1016/j.scriptamat.2015.11.020

${ }^{12}$ S. H. Huang, D. Y. Shu, C. K. Hu, S. F. Zhu, Effect of strain rate and deformation temperature on strain hardening and softening behavior of pure copper, Trans. Nonferrous Met. Soc. China, 26 (2016) 4, 1044-1054, doi:10.1016/S1003-6326(16)64201-2

${ }^{13}$ G. S. Fu, W. Z. Chen, K. W. Qian, Synthetical technique of high-efficient melt-treatment of aluminum and its effect, Chinese J. Nonfer. Met., 12 (2002), 269-274, doi:10.3321/j.issn:1004-0609. 2002.02.014
${ }^{14}$ G. Chen, G. Fu, S. Lin, C. Cheng, W. Yan, H. Chen, Simulation of flow of 3003 aluminum alloy under hot compressive deformation, Met. Sci. Heat Treat., 54 (2013) 11-12, 623-627, doi:10.1007/ s11041-013-9560-5

${ }^{15}$ M. G. Lee, S. J. Kim, Elastic-plastic constitutive model for accurate springback prediction in hot press sheet forming, Met. Mater. Int., 18 (2012), 425-432, doi:10.1007/s12540-012-3007-1

${ }^{16}$ A. Etaati, K. Dehghani, G. R. Ebrahimi, H. Wang, Predicting the flow stress behavior of Ni-42.5Ti-3Cu during hot deformation using constitutive equations, Met. Mater. Int., 19 (2013), 5-9, doi:10.1007/ s12540-013-1002-9

${ }^{17}$ E. I. Poliak, J. J. Jonas, A one-parameter approach to determining the critical conditions for the initiation of dynamic recrystallization, Acta Mater., 44 (1996) 1, 127-136, doi:10.1016/1359-6454(95) 00146-7

${ }^{18}$ K. P. Rao, Y. V. R. K. Prasad, K. Suresh, Hot working behavior and processing map of a $\gamma$-TiAl alloy synthesized by powder metallurgy, Mater. Des., 32 (2011), 4874-4881, doi:10.1016/j.matdes.2011. 06.003

${ }^{19}$ M. S. Ghazani, B. Eghbali, G. Ebrahimi, Kinetics and critical conditions for initiation of dynamic recrystallization during hot compression deformation of AISI 321 austenitic stainless steel, Met. Mater. Int., 23 (2017) 5, 964-973, doi:10.1007/s12540-017-6391-8 